\author{
Jasna Lj. Parlić Božović ${ }^{1}$ \\ UNIVERSITY OF PRIŠTINA WITH TEMPORARY HEAD-OFFICE \\ IN KosovsKa Mitrovica, FACULTY of Philosophy \\ DePARTEMENT OF PEDAGOGY \\ IVANA K. STOILJKOVIĆ ${ }^{2}$ \\ UNIVERSITY OF PRIŠTINA WITH TEMPORARY HEAD-OFFICE \\ IN Kosovska Mitrovica, Faculty of Medicine
}

\title{
CONTEMPORARY FORMS OF FAMILY AND SCHOOL COLLABORATION IN THE PROCESS OF PREPARING CHILDREN FOR STARTING SCHOOL
}

ABSTRACT. Taking into account the modern living conditions characterized by an accelerated rate of life and work, the rapid development and progress of science and technology, the role of families in preparing children for school is becoming increasingly important. The collaboration between the family and the school is also necessary because of the expectations that the society has from the educational systems to enable the child with the emotional stability and undisturbed growth and progression, and to make sure that the child accepts the transition to primary school in the best possible way. This type of collaboration is also necessary because it is one of the conditions for the manifestation of the positive effects of the upbringing and the educational process. Realization of the education and upbringing work, apart from the continuous collaboration, also implies attentiveness of the parents for some of the particular and individual ways of collaboration. It is on these assumptions that the very outcome of the collaboration between

jasnaparlic@yahoo.com

ivana.mitov@gmail.com

The paper is the result of research within the scientific project III 47023 "Kosovo and Metohija between national identity and Euro-integrations" financed by the Ministry of Education and Science of the Republic of Serbia. 
the families and the school depends. The methods and domains of the family influence are abundant and diverse and they depend upon the characteristics of the wider social community in which the child is growing up, as well as the readiness of the parents, which shall be described in this work.

The success of the Home-School Collaboration greatly depends upon the teacher's personality and the way in which the teacher communicates with the parents, as well as the teacher's readiness to meet the needs of the parents whose child is starting school. The communication channels must always be open, otherwise, the efforts might become ineffective. These assumptions will be examined theoretically and empirically in this work.

KEYWORDS: family; school; pupils; starting school.

Starting school is a very important milestone in life and as such represents a big change for the child and the parents alike. This event implies the readiness of the child to accept the new duties, and at the same time, the readiness of the parents to give their child the right support and in the right way.

The authors that are, like Milošević, actively involved with this problem, believe that a child transitioning to primary school "needs some time to adjust to the new environment, new pace of life and new responsibilities, for which they should already be well prepared" (Milošević, 2001, p. 219). It is necessary for them to accept the school from the very beginning as the place where new knowledge and new friends await. At that point, the life is changing for all members of the family and it is therefore necessary for the family as an entity to successfully and together implement the new "rules of the game" in its functioning. This primarily implies adopting the daily study routine, free time, as well as not forgetting the time for playing and other activities the child might have. It is also very important that the child takes part in setting the new rules. It is important to pay attention to the right balance and the right measure of things. Neither the rules that are too rigid or too flexible are appropriate. The adjustment of the new pupil depends equally on the child's social competence, on its ability to be accepted by its peers. The child that learns how to handle the frustrations and negative feelings will, by Milošević's opinion, also have "an easier time adjusting and being accepted by its peers" (Milošević, 2000 , p. 23). With this idea in mind, the parent can help a child solve conflicts with its peers by talking to his child and by helping his child distinguish between suitable and unacceptable behavior. 
It is therefore important to give support to the child but also encourage the child to find solutions on its own.

We are all familiar with the remarks the parents are known to make: "You will see once you start school"... "you will fail"... "you will get a detention", etc. These are fully unacceptable and can cause more harm than good, just as well as idealizing school will. It is perhaps more suitable to present a child with an approach of a different kind "... All children go to school because the school will help them grow" or "School is a place that helps us acquire useful knowledge that will help us become independent in the future", etc.

There are many skills, knowledge, and abilities that a new pupil should acquire. Some of them, that the child should master in preschool with the help of parents and preschool teachers, will be listed here: the ability to perceive and observe, the ability to verbalize and discuss in detail everything visible (during a walk, a visit to the doctor, etc), the ability to concentrate during school tasks as well as during the everyday activities (dressing, tidying up...), the child should have adopted good personal hygiene habits at meals, dressing, use of toilet, washing and drying hands..., a child should be able to say his name, surname, the names of his parents, home address, telephone number (it should also be checked whether the child is familiar with the route from home to school), a child should be able to dress himself, to put and take off his shoes, brush his teeth, comb his hair, help himself make a simple meal at home, he should learn to lock/ unlock the doors on his own, to use the telephone (to call the parents if needed), to learn to use a watch etc.

All this is necessary for a child to master in preschool. Likewise, the obligations of the parents of the future schoolchildren are also imposed, such as preparing their child for reading and writing with visual distinction for example (detecting minor differences between objects or signs), audible distinction (various speech games, songs, sound games), the adoption of time provisions (yesterday, today, tomorrow, before, after), the adoption of spatial awareness (left, right, in front, behind, above, underneath...), understanding the number concept (counting objects, playing board games), basic shapes distinction (tasks the likes of: clothing items, work tools, professions, household items...), ability of classification (domestic, wild animals, fruits, vegetables, vehicles...), as well as sorting by hierarchy, shapes, colors, kind, size...The important parental involvement has already been mentioned, however, 
the parental collaboration with the school is just as equally important for the child's successful preparation for school.

When speaking about Home and School collaboration, we must firstly picture the family as the social environment in which an individual develops and shapes, and the school as the embodiment of the institutionalized upbringing and education. These are the important factors in the development of each individual and the society as a whole (Bojanović, 1997, p. 122). Therefore, it is not unusual for the family and the school to be the subject of constant research all around the world as well as here. The psychodynamics of family life imposes many variables that are open for and need to be explored, starting from the way the children are raised and brought up, through the help and support that is given to the child, to the acquisition of the good working habit etc.

Some of the authors tried to elucidate the definition of the concept of the family and school collaboration and so did our N. Potkonjak who studied the relations between school and social environment, in doing so he found the connection between the following terms: relation, connection, collaboration, and Integration (Potkonjak \& Šimleša, 1989, p. 540). The author believes that these segments should be used from the certain points of view, that is, it is distinguishable "when we are talking about a relation, when the relation becomes the connection, the connection - collaboration and finally - integration" (Potkonjak, 2003, p. 45). Potkonjak, immediately explains that "the relation consists of at least two and, if necessary multiple systems, which can be single or entwined. The connection appears when these systems begin to work, if they can have influence on one another (Potkonjak, 2003, p. 45). The collaboration between family and school gives parents an opportunity to actively contribute by involvement in the educational activity, giving them an insight into the work of the school, as well as the results of the educational work (Potkonjak et. al, 1998, p. 118). As Professor Potkonjak said, in the second half of the last century, another essential characteristic that is inseparably connected with the systematicity is - systematic upbringing (Potkonjak, 1973, p. 32). Also, for the collaboration between the family and the school, existence of empathy is necessary, social perception, emotional attitude (empathy and antipathy), mutual trust, absence of conflicts between parents and the child/ pupil, or the teacher, something all authors agree on, listing some of these segments, “... All this is necessary for the successful collaboration and the devel- 
opment of the child's personality and successful achievements" (Potkonjak, Orlović, 1972, p. 32). It is expected from the parents to be interested in collaboration with the school, to respect the teacher's persona, but primarily to respect themselves and their child. Finally, the school, as an educational institution, according to Branković, must enable the parents to be introduced to and familiarized with the educational goals and tasks, with all their characteristics and means of realization (Branković, 1999, p. 25). In doing so, the school should certainly respect every parent as the person who joined this collaboration. Also, the collaboration between home and school is an integral part of the annual plan and program. Savić exhausts the subject with an explanation that "the collaboration should be planned by a professional body of the school, according to the school's possibilities, the available time, taking into the equation the quality of parent's education, as well as the very topic of collaboration" (Savić, 1990, p. 18). And from Savić, to this day and in so many years, in this respect, not much has changed.

Also, looking at the psychological and adaptive changes in children, starting school is one of the most critical and challenging periods in the life of a child, therefore this type of collaboration between their families and the school is necessary for all mentioned obstacles to be painlessly overcome and school accepted in the best possible way.

The basic changes and problems as well as the difficulties in adjustment of children to the school rules must be overcome by mutual and joint efforts and in the rich collaboration between the observed subjects of this process (Vidaković, 2006, p. 45). This can be achieved by establishing: work habits, time for working, study, homework, free time and other activities.

The ways home and school can collaborate during the adaptation period can be: individual contacts, parent groups, parent-teacher conferences, parent counseling groups and other ways of collaboration. 


\section{SOME RECOMMENDATIONS AS ASSUMPTIONS FOR THE SUCCESSFUL HOME-SCHOOL COLLABORATION}

The upbringing and education process depends on and can only advance if there exists the necessary collaboration between the Home and the School. If such collaboration is absent in the educational process, no progress in the pupil's upbringing and education can be expected.

1) A child should be able to grow in the happy, loving, and understanding environment in order to be able to fully and harmoniously grow and develop.

2) This kind of collaboration is necessary in order for a child to be able to prepare to live and function independently within the society.

3) The parents' involvement in the schooling process should be looked upon as a part of the developmental process.

4) The communication with the parents should be based on the pupil's progress and achievement reports to avoid the misunderstandings and difficulties, this will make sure that the educational process is effective and will consequentially help the pupil build the positive attitude toward the educational process.

5) There is an imposing need for the parents of the schoolchildren to be methodically introduced to the goals, program, logistics, realization conditions, and results of the upbringing and educational process within school. It is considered that the teaching staff's activities should not be merely reduced to the teaching curriculum and pupil's progress and achievement reports.

6) It is also necessary to establish a system of continuous feedback so that the teacher and the pupil alike as well as the parents may keep track of the progress in education. It is very important to choose the type, methods, and content of the collaboration wisely. The parents are in general more willing to accept the occasional, unmethodical collaboration brought by some concrete cause.

7) The parents are most likely to be aware of the subject and interests the child/pupil has an inclination towards or has already 
achieved good results at. The school and parents should support the pupil to excel at those subjects by joint efforts, while making sure, at the same time, that the other subjects are not being neglected.

8) Finally, the success of collaboration depends a great deal on the teacher's personality and the way in which they communicate to the parents.

9) Education of the observed subjects of this process is also necessary. This is what Grandić also writes about. Inter alia, he believes that "the changes cannot be achieved quickly and the spectacular results of the lasting character cannot be expected" (Grandić, 2004, p. 81). He wishes to say that the incorrect views on upbringing and education did not just appear quickly in some short period of time, so they cannot be altered quickly. The new content and the new habits that the parents and teachers need to adopt require continuous efforts. Milošević agrees with this thesis adding that the collaboration of the family and the school is a process that "cannot be successfully implemented without improving the process of work, permanent professional development, and knowledge of certain methods, content, and communication skills" (Milošević, 2016, p. 227).

Finally, the successful communication between the parents and the teacher/ Home and School is crucial for success, activity and work of the child that is starting school. The efforts must be made during the time of transition to elementary school and before, in the very process of preparation of children for the school so that all these efforts will lead to success of the pupil.

\section{THE RESEARCH METHODOLOGY}

The Research Problem. Both the child and his family are going through a lot of confusion and insecurities during this transitional time. This research engages in finding ways to help families of the future pupils through this challenging time through their collaboration with the school.

It is a fact that there is exceptional significance of the family for the individual and the society alike and it is necessary to focus 
more attention on its functioning in altered living conditions such as starting school.

The Subject of the Research is closely connected and arises from the basic problem of the research. The viewpoints and the opinions of the teaching staff of elementary schools in Kosovska Mitrovica towards the changes and characteristics within the families they encounter and whose children are starting school and their readiness to collaborate with the school are both important and necessary.

The Objectives, Tasks, and Hypothesis of Research: From the set subject of the research there emerges the following aim: The significance and strengthening of the collaboration between the family and the school which exists or does not exist in the school adaptation period.

The Descriptive Objective of the Research: Description and viewpoints of the teaching staff regarding the willingness of the parents of the future pupils to cooperate.

The Tasks of the Research are:

1) The fundamental task of the research is to establish the conditions for the existence of home and school collaboration.

2) To establish whether there is existence of the home-school collaboration.

3) Establishing the inclination of the families (parents) towards the collaboration with the school during the adaptation period.

4) Determine the reasons for the lack of interest of some families for the collaboration with the school.

5) Examine the lack of readiness of the teaching staff to meet the needs of the parents whose children are preparing for the school.

6) Investigate the importance and the significance that home and school collaboration has for the children who are starting school.

Hypothesis of the Research: The research attempted to test several hypotheses:

1) Starting from the basic goal of the research, it is assumed, by the general hypothesis, that there is collaboration between home and school.

2) It is assumed that the collaboration between home and school is not satisfactory for numerous reasons. 
3) It is assumed that the teachers believe the leading problem is that the families are not prepared to participate in this way of collaboration.

4) It is assumed that certain families of the future schoolchildren lack interest to collaborate with the school and are not even considering it.

5) It is assumed that the families believe the leading problem is the lack of readiness and skillfulness of the teaching staff to meet the needs of their children during this very important milestone.

6) It is assumed that teachers believe more attention should be given to the preparation of the children that are to be starting school and that in this process the home school collaboration would be of exceptional importance and significance.

Variables of the Research: Defining the variables of the research in accordance with the subject, goals, tasks, and hypotheses, and determining their mutual relationship. Variables represent the viewpoints of the teachers who will take part in the study.

Unchangeable Variables are years of service of the teachers, gender of the respondents (male-female), the school they work in.

The Dependent Variable in this case presents the consequence of the independent variables (teacher's years of service, gender, school) that are the consequence of the dependent variable (teacher's viewpoints).

The Independent Variables were measured by the standard questionnaire that contained questions about the gender (1- female gender, 2- male gender), years of service of the teaching staff as well as the school the teachers work in.

The Dependent Variable refers to teacher's viewpoints on the importance of the collaboration between families and school during the child's adaptation period.

The Method of the Research that was used was chosen in accordance with the nature of the problem, the subject, the goals, and tasks of the research, as well as in accordance with the set hypothesis. The descriptive method of theoretical analysis of the contents was used in the research.

Research Techniques The Survey was used for this research. This technique provided the relatively relevant results and information on the significance of home and school collaboration during the 
period of starting school. The family members of the children starting school were also interviewed in order to achieve the relevant results.

The Instruments of the Research The Questionnaire, specifically designed for this purpose was used as the basic instrument of the research. It is with this instrument of the research that the elementary school teachers in Kosovska Mitrovica were tested.

Model and Information Interpretation: The research was carried out in four elementary schools as well as a few families of first grade pupils. Other numerous sources were also used for the realization of this work.

\section{INTERPRETATION AND ANALYSIS OF THE RESEARCH RESULTS}

Viewpoints and Opinions of the Teachers about the Importance of Home-School Collaboration within the Child's School Entry Preparation Program

\begin{tabular}{|l|l|l|}
\hline \multicolumn{1}{|c|}{ ELEMENTARY SCHOOL } & \multicolumn{1}{|c|}{ PERCENTAGE } & \multicolumn{1}{c|}{ FREQUENCY } \\
\hline Sveti Sava & $25 \%$ & 4 \\
\hline Branko Radičević & $25 \%$ & 4 \\
\hline Dositej Obradović & $25 \%$ & 4 \\
\hline Veljko Banašević & $25 \%$ & 4 \\
\hline Total & $100 \%$ & 16 \\
\hline
\end{tabular}

TABLE 1: DistRIBUTION OF ANSWERS TO THE QUESTION: WHICH SCHOOL DO YOU WORK IN?

TABELA 1. DISTRIBUCIJA ODGOVORA NA PITANJE U KOJOJ ŠKOLI RADE ISPITANICI

\begin{tabular}{|l|l|}
\hline \multicolumn{1}{|c|}{ YeARS OF SERVICE } & \multicolumn{1}{c|}{ PeRCENTAGE } \\
\hline Less than 5 & $18 \%$ \\
\hline $5-10$ & $32 \%$ \\
\hline $10-20$ & $28 \%$ \\
\hline
\end{tabular}

TABLE 2: DistRIBUTION OF ANSWERS TO THE QUESTION: YEARS OF SERVICE OF THE TEACHERS? TABELA 2. DISTRIBUCIJA ODGOVORA NA PITANJE: GODINE RADNOG STAŽA UČITELJA - UČITELJICA. 
CONTEMPORARY FORMS OF FAMILY AND SCHOOL COLLABORATION...

\begin{tabular}{|l|l|}
\hline Over 20 & $22 \%$ \\
\hline Total & $100 \%$ \\
\hline
\end{tabular}

TABle 2: Distribution OF ANSWERS TO THE QUESTION: YEARS OF SERVICE OF THE TEACHERS? TABela 2. DISTRIBUCIJA ODGOVORA NA PITANJE: GODINE RADNOG STAŽA UČITELJA - UČITELJICA.

According to the years of service of the respondents the following results were obtained. $18 \%$ of the respondents that took part in this research had less than five years of service, $32 \%$ were the respondents that had between 5-10 years of service, $28 \%$ were the respondents with 10-20 years of service and $22 \%$ were those with over 20 years of service behind them.

Out of the total of 12 teachers/ respondents, that took the part in the research, $83.33 \%$ were female (10 teachers) and $16.33 \%$ were male (2 teachers).

\begin{tabular}{|l|l|}
\hline \multicolumn{1}{|c|}{ IS THERE A COLLABORATION BETWEEN FAMILY AND SCHOOL } & \multicolumn{1}{c|}{ PERCENTAGE } \\
\hline Yes & $14 \%$ \\
\hline Yes, but it is not satisfactory & $70 \%$ \\
\hline No & $16 \%$ \\
\hline TOTAL & $100 \%$ \\
\hline
\end{tabular}

TABLE 3: DISTRIBUTION OF ANSWERS TO THE QUESTION: IS THERE A COLLABORATION BETWEEN HOME AND SCHOOL DURING THE CHILDREN'S SCHOOL ADAPTATION PERIOD? TABELA 3. DISTRIBUCIJA ODGOVORA NA PITANJE: DA LI POSTOJI SARADNJA PORODICE I ŠKOLE U OKVIRU PROGRAMA PRIPREME DECE ZA POLAZAK U ŠKOLU?

To the question whether there is home-school collaboration during the children's school entry preparation program, the highest number of the respondents, $70 \%$ answered yes, but the collaboration is not satisfactory, $16 \%$ of the respondents replied no, and $14 \%$ of the respondents replied yes.

These responses confirmed the hypothesis about the existence of home school collaboration during the children's school adaptation period. The hypothesis that the mentioned collaboration is not satisfactory was also confirmed. There are numerous reasons that led to these results. 


\begin{tabular}{|l|l|}
\hline \multicolumn{1}{|c|}{$\begin{array}{c}\text { THE REASONS FOR UNSATISFACTORY } \\
\text { COLLABORATION }\end{array}$} & PERCENTAGE \\
\hline Parent's unconcern & $48 \%$ \\
\hline Parent's ignorance & $22 \%$ \\
\hline Parent's poor quality education & $30 \%$ \\
\hline TOTAL & $100 \%$ \\
\hline
\end{tabular}

TABLE 4: DISTRIBUTION OF ANSWERS TO THE QUESTION: REASONS FOR THE UNSATISFACTORY COLLABORATION. TABELA 4. DiSTRIBUCIJA ODGOVORA NA PITANJE : RAZLOZI ZA NEZADOVOLJAVAJUĆU (NEUSPEŠNU) SARADNJU

By looking into these answers, we see that, unfortunately, parents lack the time, the energy, and the knowledge or do not consider themselves competent and fail to understand the role they have in their children's education and how their children can benefit from their collaboration with the school during the school adaptation period.

Thus, to the question What are the reasons for the unsatisfactory collaboration between home and school? $48 \%$ of the respondents thought that the reason for this was parent's unconcern and 30\% agreed that the reason for this was poor quality of education of the parents.

\begin{tabular}{|l|l|}
\hline \multicolumn{1}{|c|}{$\begin{array}{c}\text { The SignifiCANCE Of HOME-SCHOOL } \\
\text { COLLABORATION }\end{array}$} & PERCENTAGE \\
\hline $\begin{array}{l}\text { The Home-School Collaboration is of utmost } \\
\text { significance for the preparation of children } \\
\text { for school }\end{array}$ & $97 \%$ \\
\hline $\begin{array}{l}\text { The Home-School Collaboration is of great } \\
\text { significance, but it is not crucial }\end{array}$ & $3 \%$ \\
\hline $\begin{array}{l}\text { The Home-School Collaboration is of no sig- } \\
\text { nificance for the preparation of children for } \\
\text { school }\end{array}$ & $0 \%$ \\
\hline TOTAL & $100 \%$ \\
\hline
\end{tabular}

TABLE 5: DistRIBUTION OF ANSWERS TO THE QUESTION: TEACHERS' OPINIONS ON THE SUBJECT OF THE SigNificANCE OF COLLABORATION BETWEEN FAMILIES AND SCHOOL? TABELA 5. DiSTRIBUCIJA ODGOVORA NA PITANJE: STAVOVI UČITELJA - UČITELJICA O ZNAČAJU SARADNJE PORODICE I ŠKOLE 
These results demonstrate the fact that the teachers consider the collaboration between families and school to be of great significance for the preparation of children for the transition to primary school. $97 \%$ of the respondents consider the Home - School collaboration highly significant for the preparation of children for school.

\begin{tabular}{|l|l|}
\hline Methods of Collaboration Improvements & Percentage \\
\hline $\begin{array}{l}\text { Improving awareness of families about strat- } \\
\text { egies of effective collaboration }\end{array}$ & $49 \%$ \\
\hline $\begin{array}{l}\text { Involving Government in the preparation } \\
\text { program and strategies of collaboration }\end{array}$ & $28 \%$ \\
\hline $\begin{array}{l}\text { Better preparation of the teaching staff for } \\
\text { working together with the families }\end{array}$ & $23 \%$ \\
\hline TOTAL & $100 \%$ \\
\hline
\end{tabular}

TABLE 6: DISTRIBUTION OF ANSWERS TO THE QUESTION: TEACHERS' OPINIONS ON THE SUBJECT OF METHODS OF IMPROVEMENT OF COLLABORATION BETWEEN FAMILIES AND SCHOOL? TABELA 6. DistRIBUCIJA ODGOVORA NA PITANJE: STAVOVI UČITELJA-UČITELJICA O NAČINIMA POBOLJŠANJA SARANJE PORODICE I ŠKOLE

As means of improvement of Home and School Collaboration, $49 \%$ of the respondents cited that families/ parents should be better informed about strategies of effective collaboration with the School/ Teacher, 28\% thought the Government should be involved in the pupils' school preparation program as well as the teaching staff being better prepared for working together with the families. Out of all given answers one can clearly conclude that that the teachers view the Home-School collaboration as a matter of exceptional significance for the preparation of children for the transition to primary school, which confirmed the hypothesis of research.

\section{APENDIX 1}

\section{QUESTIONNAIRE}

\section{Dear Sir/Madam}

We would like to ask for cooperation in research on the topic Opinions and attitudes of teaching staff on the importance of home and school collaboration in the program of preparing children for school. 
Please answer all questions honestly, as this will contribute to a better understanding of the phenomenon being studied.

1) Gender?
a) Female
b) Male

2) Birth place, Municipality, Country?

3) Which school do you work in?
a) ES Sveti Sava
b) ES Branko Radičević
c) ES Dositej Obradović
d) ES Veljko Banašević

4) Years of service:
a) Less than 5 years
b) $5-10$ years
c) $10-20$ years
d) over 20 years

5) Teachers' opinions on the subject of The Significance of Collaboration between Families and School?
a) Yes
b) Yes, but it is not at a satisfactory level.
c) No

6) What are the reasons of unsatisfactory level of home-school collaboration in the program of preparing children for school?
a) Indifference of parents
b) The lack of information from parents about the types of collaboration
c) Parents' low education level

7) What are the ways to improve home-school collaboration in the program of preparing children for school?
a) Improving parents' awareness about the types of collaboration with the school
b) Involvement of the state in collaboration
c) Better training of teaching staff for collaboration

THANK YOU FOR YOUR COLLABORATION!!! 


\section{APENDIX 2}

Here we have the two parent's diametrically opposed experiences used as examples of collaboration between Home and School within the school preparation program.

"I have two children. The older is just finishing the first grade and younger is starting school in September. My experience with the older child was a very positive one. Both the school my child attends and the child's teacher has been of great help. From the very first interview with the school's educationalist, educational psychologist, all through the exceptional cooperation I had with the assigned teacher and the school director alike. Prior to even meeting the children, the teacher visited families of all the pupils she was to teach, which I considered to be of outmost importance. Getting familiar with the child's family background, she learned a lot about the children, which later proved to be of great help in managing the transition to primary school. I believe that good Home-School collaboration is of great benefit for the children" (J.M. 38 years old, machine engineer).

"My child just started third grade. It has been going to school on its own from the first grade. I took my child to school only once, on the first day of school. I am not familiar with the name of the teacher. I do not have the time to attend the teacher-parent meetings since I need to work two jobs in order for us to make ends meet. It is better for the child to learn to fend for himself, it will make his life easier in the future. I am not interested in collaboration with the school. We have nothing to collaborate on" (S.N., 33 years old, worker)

REFERENCES Branković, D. (1999). Pedagogical theories. Banja Luka: Scientific basics and developmental flows.

Bojanović, R. (1997). The Democratic and antidemocratic personality. Belgrade: Education for democracy, Dialogue, no. 3-4.

Vidaković, I. (2006). Dictionary of Social Work. Belgrade: The National Library of Serbia.

Grandić, R. (2004). Annexes to family Pedagogy. Novi Sad: Author's Edition.

Milošević, I. (2000). Family and family education. The collection of the Institute for Pedagogical Research, Belgrade: The Institute for Pedagogical Research and Education.

Milošević, N. (2001). Retelling as a means to encourage the culture of speech in school. The collection of the Institute for Pedagogical Research, Belgrade: The Institute for Pedagogical Research and Education. 
Milošević, N. (2016). Two language codes: family and school. Belgrade: The Institute for Pedagogical Researches.

Potkonjak, N. \& al. (1998). Pedagogical Lexicon 2. Belgrade: The Institute for Textbooks and Teaching Resources.

Potkonjak, N., Orlović-Potkonjak, M. (1973). The 20th century is not a "child's life" nor a century of pedagogy has hopes .... XXI century. Novi Sad: Association of Pedagogical Societies of Vojvodina.

Potkonjak, N., Orlović- Potkonjak, M. (1973). Pedagogy, the first part. Belgrade: The Institute for textbooks and Teaching Resourses.

Potkonjak, N. \& Šimleša, P. (1989). Pedagogical Encyclopedia, Book 2. Belgrade: The Institute for Textbooks and Teaching Resources.

Savić, M. (1990). How to make your child a successful pupil. Belgrade: The Children's Newspapers, The National Library of Serbia.

\author{
ЈАСНА Љ. ПАРЛИЋ БОЖОВИЋ \\ УНИВЕРЗИТЕТ У ПРИШТИНИ СА ПРИВРЕМЕНИМ СЕДИШТЕМ \\ У КОСОВСКОЈ МИТРОВИЦИ, ФИЛОЗОФСКИ ФАКУЛТЕТ \\ КАТЕДРА ЗА ПЕДАГОГИЈУ \\ ИВАНА К. СТОИљКОВИЋ \\ УНИВЕРЗИТЕТ У ПРИШТИНИ СА ПРИВРЕМЕНИМ СЕДИШТЕМ \\ У КОСОВСКОЈ МИТРОВИЦИ, МЕДИЦИНСКИ ФАКУЛТЕТ
}

РЕЗИМЕ

\title{
САВРЕМЕНИ ОБЛИЦИ САРАДЊЕ ПОРОДИЦЕ И ШКОЛЕ У ПРОЦЕСУ ПРИПРЕМЕ ДЕЦЕ ЗА ПОЛАЗАК У ШКОЛУ
}

Полазак у школу је врло значајан доживљај за дете. Од првог утиска детета о школи зависи успешност његовог даљег школовања, па се може сматрати и пресудним тренутком за цели живот детета. Поласком детета у школу, круг око њега се шири. Игра више није основа већ учење постаје његова основна активност. Дете ће напредовати у школи и лепо се осећати у друштву својих вршњака ако код детета формирамо позитиван однос према школи, обавезама које га чекају, спремности за учење и рад, однос према учитељу и пријатељима.

Полазак у школу важна је прекретница у животу детета. У проучавању везе између породице и школе утврдили смо да је сарадња породице и школе за полазак детета у школу од изузетне важности. Укључивање детета у образовни процес сматра се значајним фактором бољег прилагођавања и развоја личности ученика. 
Васпитање и образовање брига су и породице и школе, тако да

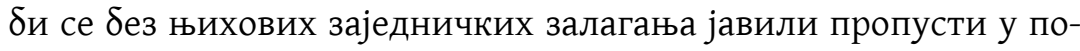
стизању васпитно-образовних и наставних циљева и задатака. Све ово што породица подстиче и развија, школа треба да продубљује, а све оно што се у школи развија породица треба да подстиче. Из резултата истраживања може се, такође, извести закључак да је сарадња породице и школе од велике важности и да доприноси ठољем сналажењу деце приликом поласка у школу. Евидентно је да ће деца чији су родитељи процентуално више укључени у школске активности постићи бољи успех у учењу и бити срећније, задовољније и здравије личности од деце чији ће родитељи у мањем степену ठити укључени у школске активности. Породица је, свакако, модел и узор у усвајању друштвено-социјалних облика понашања и изградње основних црта личности. Школа је најважнија институција где се ти облици шире и продуठљују, па из тога проистиче то да је сарадња породице и школе императив за успех и напредак деце.

Сарадња породице и школе треба да се остварује од тренутка када дете постане полазник образовне установе, а надаље да се продубљује и допринесе адекватном испуњавању васпитно-образовних задатака у школи.

Социјализација, начини сарађивања и изграђивања односа који започињу у породици бивају допуњавана и утицајима других, ширих, спољашњих фактора (школа, средства масовне комуникације и др.), који утичу на формирање зреле и стабилне личности.

И најзад, поласком у школу, деца ступају у односе који су за њих нови и другачији од односа у породици, при чему је сарадња породице и школе од круцијалног значаја за развој и сазревање личности детета, што нажалост, сви родитељи, још увек не схватају.

КљУчнЕ РЕчи: породица; школа; ученици; полазак у школу.

Овај чланак је објављен и дистрибуира се под лиценцом Creative Commons Ауторство-Некомерцијално Међународна 4.0 (СC BY-NC 4.0 |

https://creativecommons.org/licenses/by-nc/4.0/).

This paper is published and distributed under the terms and conditions of the Creative Commons Attribution-NonCommercial International 4.0 licence (CC BY-NC 4.0 | https://creativecommons.org/licenses/by-nc/4.0/). 